\title{
The Impact of Ethics on Financial Report of Corporate Organizations in Nigeria
}

\author{
${ }^{1}$ Obasesin Moses Odunayo \\ ${ }^{2}$ Olaoye Festus Oladipupo \\ 1. Department of Accounting, Faculty of Management Sciences, Ekiti State University, Ado-Ekiti \\ 2. Department of Accounting, Faculty of Management Sciences, Ekiti State University, Ado-Ekiti
}

\begin{abstract}
The purpose of this research was to examine the impact of ethics on financial report of corporate organizations in Nigeria. This paper explores the role of accounting professionals on financial reporting towards the users of accounting information. The study adopted population sample of corporate organizations in Nigeria, specifically those residents in Lagos State. The study is highly descriptive and empirical embracing the use of questionnaire as the primary source of data with results presented on percentages, average and standard deviation. The target respondents were finance professionals comprising accountants and auditors of corporate organizations in Lagos State. To achieve the objective of the study, 50 questionnaires were administered to the finance professionals. Of the 50 questionnaires administered, 40 was retrieved which underwent required analysis and the one way ANOVA technique was used to test the hypothesis. Findings from the research revealed ethics have a significant impact on financial report of corporate organizations in Nigeria. It was recommended, corporate organizations should imbibe qualitative recruitment process, full adoption of the international financial reporting standards in their accounting policies, firms should establish a compliance department in their respective offices while regulatory agencies of the government should do proper monitoring of business enterprise on ethical guidelines compliance.
\end{abstract}

Keywords: Accountability; Ethics; Financial Report; Reporting Entity

\subsection{Introduction}

The significance of financial reporting to a business organization cannot be overemphasized with consideration of its usefulness to users of accounting information such as owners, management, creditors, employees, government and its agencies, trade unions, researchers, community, financial analysts and advisers. In Nigeria, the collapse of corporations such as Skye Bank, Diamond Bank, Savannah Bank, Oceanic Bank, African Petroleum and Intercontinental Bank has place priority on the need to give ethics necessary importance. Ethical issues on financial report of local and international business organization determine the success or failures of their operations. Professional accountants are responsible to users of 


\section{International Conference on Advanced Research in MANAGEMENT, ECONOMICS AND ACCOUNTING}

\section{5-7 September, 2019}

Barcelona, spain

MEA

MANAGEMENT, ECONOMICS \& ACCOUNTING CONFERENCE

accounting information and the accounting profession as a whole. The preparation and presentation of financial information aiding decision making plays a fundamental role in the activities of stakeholders. Ugbogbo (2016) opined ethics carried along moral values, normative judgments and moral obligations, thus expected of every accountant. White (2002) considered ethics as principles of reason with emphasis on consequentialism, Kantian deontologism, natural law and virtue. The plurality theory of Resnik (2010) mandates professional accountants on doing the right thing. Recognized accounting professional bodies develops and issues ethical codes to members which serves as a guidelines on their professional conducts and responsibilities. The research carried out by Talebinia, Salehi and Jabbarzade (2011) reveals the basis of quality financial report is seen in the entity's honest dealings. This according to Mahsoud (2013) will be noted in the organization's practice and environment.

This study adds to existing knowledge on ethics in financial report of corporate organizations in Nigeria. To the best knowledge of the author, there have not been enough research conducted on this particular field of study in Nigeria, thus this will assist present and future researchers in their quest for knowledge on this field. The objective of this paper is to examine the impact of ethics on financial reporting with consideration to corporate organizations in Nigeria. Section 2 reviews literature, section 3 discusses methodology of the research, section 4 analyses the data and section 5 concludes with recommendations to the study.

\subsection{Body of paper}

\subsection{Ethics in Financial Reporting}

The unethical financial reporting as seen in corporate organizations affects employees, firms and the economy as a whole. In the United States of America, the Financial Accounting Standards Board (FASB), Securities and Exchange Commission (SEC) and the Public Company Accounting Oversight Boards (PCAOB) watch over the financial report of corporate organizations (Mantzke, Carnes and Tolhurst, 2005). In Nigeria, professional accounting bodies such as the Institute of Chartered Accountants of Nigeria, Association of National Accountants of Nigeria and the Chartered Institute of Taxation of Nigeria issues codes on professional competence, due care, integrity, confidentiality, objectivity and professional behavior to members. Also, the International Federation of Accountants (IFAC), the global body regulating accounting practice regularly mandates members on the need to demonstrate high level of ethical compliance in financial reporting.

Accounting operates on the going concern concept, cost principle and objectivity. The principles of consistency, full disclosure, materiality and conservatism are fundamental to financial reporting. The use of unethical way financial documents will mislead investors (Accounting Zone, 2019). 


\title{
International Conference on Advanced Research in MANAGEMENT, ECONOMICS AND ACCOUNTING
}

\author{
5-7 September, 2019
}

Barcelona, spain

MEA

MANAGEMENT, ECONOMICS \& ACCOUNTING CONFERENCE

\subsection{Empirical Review}

Erderhe (2004) emphasized structures, transparency and trust as essentials tools in ethics. The elimination of the trio according to him could shrink or collapse a business organization. According to him, the Global Reporting Initiative as launched in 1997 by the United States government enhances qualitative reporting with support from the government, corporate organizations, non-governmental organizations and trade unions. Karaibrahimoglu, Erdeher and Var (2009) concluded educational process and leadership as key in promoting ethical values for accounting education. Reliability, neutrality and transparency were noted as ethical concepts for personal convictions about right and wrong. The research executed by Onyebuchi (2011) on ethics in accounting, was of the view there is no global acceptable approach in addressing ethical issues. Mahdi and Mohson (2012) conducted a study of 215 companies in Iran with a 24 questionnaires on ethics and financial reporting quality. Their research findings revealed professional ethics promotes a qualitative financial reporting. Masoud and Mahbude (2013) opined on the role of accountants to owners, employees', government, shareholders, profession and members of the public. Been an essential element of the accounting profession, there is high dependence on moral leadership. They asserted on synergy of ethics and quality financial reporting.

Enofe, Edemenya and Osunbor (2013) recapped the role of the United States of America government Sarbanes - Oxley Act of 2002 and the Public Company Accounting Oversight Board in pressuring accountants with the charge for more knowledge on ethics to prevent reoccurrence of the Enron, Arthur Anderson and World com saga. The Cadbury Plc, African Petroleum, Oceanic Bank and Societe General Bank to mention a few is a wakeup call to the government of Nigeria on the need to strengthen the code of corporate governance. Their research centered on the effect and extent to which ethics affect financial reports. Kermis and Kermis (2014) opined societal, personal, institutional and professional values as ethical concepts. The American values are seen in democratic utilitarianism, individual rights and selffulfillment, right to truth, equality and efficiency in work with organization playing crucial role in accounting ethics. Hou (2014) enumerated economic environment, organizational structures, production and business operation as challenges faced by financial accounting. He suggested harmonization of accounting as well as technology support to solve the challenges. He concluded sound knowledge of accounting development pattern especially in age when economy and society progresses rapidly would aid the solution. Adegbite and Fofah (2016) concluded that the four pillars of corporate governance which are accountability, independence, fairness and transparency cannot be deleted from financial reports of business organizations. The financial reports contain reliable facts and faithfulness in contents which it proves that the business organization is presenting a sustainable performance that will attract investors and relevant stakeholders. Trust and confidence have been identified over time as the key blocks for laying the foundation of survival and profitability in the banking industry. .With the adoption of International Financial Reporting Standard by countries all over the global village which helps to produce harmonized financial reports, Financial Reporting Council of Nigeria will need to ensure full compliance of all the relevant standards for quality, reliable and faithful financial reports. The Nigerian regulatory authorities need to enhance the level of supervision of Nigerian banks in view of the enhanced capital base and the global connection of economies where financial reports are considered as very important financial documents that will aid 
foreign direct investment into an economy. Pandey (2017) asserted going concern concept, historical accounting, measurement, consistency and development of International Financial Reporting Standard as challenges confronting financial reporting and accounting. He opined deceitful financial reporting, assets misappropriation, fraud and error as ethical issues in accounting and financial reporting. He suggested consistency significance, investment in information technology system, management and internal supports as solutions to ethical issues relating to financial reporting.

\subsection{Methodology}

This research seeks to determine ethical issues in financial reporting. The primary source of data was questionnaire with the use of 4 point Likert scale of Strongly Agree (AS), Agree (A), Disagree (D) and Strongly Disagree (SD). The population of study comprises Nigerian professionals in the field of accounting as practitioners in Lagos State were the sample for study. Results were presented using percentages, averages and standard deviation. A total of 50 questionnaires were administered to the respondents, while 40 were retrieved representing $80 \%$. The percentage retrieved was alright. These were analyzed using the One-Way ANOVA technique. The test of significance is performed using n-1 degree of freedom @ 5\% level of significance.

\subsection{Data Analysis}

\subsubsection{Presentation of Data}

Table 1: Distribution of Responses on the Impact of Ethics on Financial Report of Corporate Organizations in Nigeria.

\begin{tabular}{|c|c|c|c|c|c|}
\hline & & 4 & 3 & 2 & 1 \\
\hline & & SA & A & $\mathrm{D}$ & SD \\
\hline & Ethics and Corporate Organizations' Financial Report & $\%$ & $\%$ & $\%$ & $\%$ \\
\hline 1 & Business organizations are transparent in financial reporting & 22.5 & 35 & 20 & 22.5 \\
\hline 2 & Ethical financial reporting is the responsibility of Directors & 47.5 & 25 & 12.5 & 15 \\
\hline 3 & There is sound internal control system & 37.5 & 40 & 10 & 12.5 \\
\hline & Management decisions affect preparation of financial report & 42.5 & 40 & 10 & 7.5 \\
\hline 5 & Ethical irregularities are functions of management decision & 35 & 37.5 & 17.5 & 10 \\
\hline & Statutory codes guides business organizations operation & 30 & 32.5 & 12.5 & 25 \\
\hline & Business operations supervision is not sound enough & 35 & 40 & 17.5 & 7.5 \\
\hline & Management are supervised by relevant statutory codes & 35 & 30 & 15 & 20 \\
\hline & Penalties to correct irregularities discourage unethical acts & 52.5 & 40 & 5 & 2.5 \\
\hline & Issued codes ensure ethicality in business operations & 45 & 35 & 7.5 & 12.5 \\
\hline & Source: Survey & & & & \\
\hline
\end{tabular}




\section{International Conference on Advanced Research in MANAGEMENT, ECONOMICS AND ACCOUNTING}

\section{5-7 September, 2019}

Barcelona, spain

MEA

MANAGEMENT, ECONOMICS \& ACCOUNTING CONFERENCE

Control Activities: Of the 40 respondents, $57.5 \%$ were of the opinion business organizations are transparent in financial reporting while $42.5 \%$ disagreed. On whether ethical financial reporting is the responsibility of directors, $72.5 \%$ of the respondents agreed while $27.5 \%$ disagreed. Also, $77.5 \%$ respondents vouched of sound internal control system as $22.5 \%$ have contrary view. On management ethical or unethical decisions affect preparation of financial report, $82.5 \%$ of the respondents agreed while $17.5 \%$ disagreed. As observed, ethical irregularities in business reporting are largely a function of management's decision, $72.5 \%$ of the respondents agreed to this while $27.5 \%$ of the respondents who attended to the questionnaire depicted contrary opinion. $62.5 \%$ of the respondents agreed there are statutory codes guiding business organizations operation in Nigeria but $37.5 \%$ of the respondents held a contrary opinion. The issue on level of supervision of business operations in Nigeria is not sound enough attracted positive interest of $75 \%$ while a group of $25 \%$ respondents demonstrated a contrary view. Furthermore, $65 \%$ of the respondents agreed management is supervised by relevant statutory codes as $35 \%$ of the respondents held a contrary view. On whether available penalties to correct irregularities are responsible to discourage unethical practices, $92.5 \%$ of the respondents depicted a positive view while 7.5 of the respondents representing disagreed. Lastly, $80 \%$ of the respondents agreed issued code ensures ethicality in business operations while $20 \%$ have a contrary view.

\subsubsection{Analysis of Data}

Table 2: Analysis of Responses on the Impact of Ethics on Financial Report of Corporate Organizations in Nigeria.

\begin{tabular}{|c|c|c|c|c|}
\hline \multicolumn{2}{|c|}{ Ethics and Corporate Organizations' Financial Report } & Mean & Std Dev. & Variance \\
\hline 1 & Business organizations are transparent in financial reporting & 2.42 & 1.083 & 1.174 \\
\hline 2 & Ethical financial reporting is the responsibility of Directors & 1.95 & 1.108 & 1.228 \\
\hline 3 & There is sound internal control system & 1.97 & 1.000 & .999 \\
\hline 4 & Management decisions affect preparation of financial report & 1.83 & .903 & .815 \\
\hline 5 & Ethical irregularities are functions of management decision & 2.03 & .974 & .948 \\
\hline 6 & Statutory codes guides business organizations operation & 2.32 & 1.163 & 1.353 \\
\hline 7 & Business operations supervision is not sound enough & 1.98 & .920 & .846 \\
\hline 8 & Management are supervised by relevant statutory codes & 2.20 & 1.137 & 1.292 \\
\hline 9 & Penalties to correct irregularities discourage unethical acts & 1.57 & .712 & .507 \\
\hline & Issued codes ensure ethicality in business operations & 1.87 & 1.017 & 1.035 \\
\hline
\end{tabular}

Source: Authors Computation 
International Conference on Advanced Research in MANAGEMENT, ECONOMICS AND ACCOUNTING

\subsubsection{Test of Hypothesis}

Table 3: Ethics and Corporate Organizations Financial Report

ANOVA - Single factor

\begin{tabular}{|ccccccc|}
\hline Sources of Variation & Sum of Squares & df & Mean Square & F & Sig & F Crit \\
\hline Between Groups & 293.991 & 3 & 97.997 & 567.31 & 0.000 & 2.87 \\
\hline Within Groups & 57.935 & 36 & 1.61 & & & \\
\hline Total & 351.926 & 39 & & & & \\
\hline
\end{tabular}

\section{Hypothesis:}

H0: Ethics have no significant impact on financial report of corporate organizations in Nigeria

H1: Ethics have significant impact on financial report of corporate organizations in Nigeria.

At the level of significance 0.05 , with degree of freedom at 3 and 36 , observed $\mathrm{F}$ is 567.31 which is greater than 2.87 . H0 is hereby rejected, thus ethics have significant impact on financial report of corporate organizations in Nigeria.

\subsection{Conclusion and Recommendations}

As observed, the responsibility of directors, transparency in financial reporting, sound internal control system and statutory codes on corporate governance are fundamental to the impact of ethics on financial report of corporate organizations in Nigeria. Questionnaires were administered while gathering data and hypothesis tested with the One Way ANOVA technique. Findings show ethics have significant impact on financial report of corporate organizations in Nigeria.

The following recommendations are provided to impact ethics on financial reports of corporate organizations in Nigeria:

a. Corporate organization must ensure qualitative recruitment process of accounting professionals into its workforce in the interest of professionalism.

b. The full adoption of the International Financial Reporting Standard by corporate organizations would enhance transparency and produces quality financial report.

c. The establishment of compliance department such as internal audit by corporate organizations ensures strict adherence to accounting and internal control system. 


\section{International Conference on Advanced Research in MANAGEMENT, ECONOMICS AND ACCOUNTING}

\section{5-7 September, 2019}

Barcelona, spain

$\mathrm{M}_{\mathrm{E}} \mathrm{A}$

MANAGEMENT, ECONOMICS \& ACCOUNTING CONFERENCE

d. Proper monitoring by regulatory agencies of government such as Securities and Exchange Commission with support from professional accounting bodies on training would ensure adequate compliance on ethical code.

\section{References}

Adegbite, F.F. and Fofah, E.T. (2016). Ethics, Corporate Governance and Financial Reporting in the Nigerian Banking Industry: Global Role of International Financial Reporting Standards. Accounting \& Finance Research, Volume 5, Number 1. www.sciendupress.com

Barr, A. (1957). Some Challenges in Financial Reporting for Regulatory Agencies. New Orleans. American Institute of Certified Public Accountants.

Enorfe, A. O. Edemenya, C. C. and Osunbor, E. O. (2013). The Effect of Accounting Ethics on the Quality of Financial Reports of Nigerian Firms.

Erderhe, G. (2004). The Effects of Financial Reporting, the Global Reporting Initiative and the Balanced Concept of the Firm. www.brekert.com

Hou, X. (2014). Challenges Faced by Financial Accounting \& Suggested Solutions. International Business and Management, Volume 9, Number 2, Page 115 - 118. https://www.cscanada.org/net/index-php/ibm/article/download/5525/pdf_103

Karaibrahimmoglu, Y. Z. Erdeher, E. and Var, T. (2009). Ethical Behaviour in Accounting: Some Evidence from Turkey. African Journal of Business Management. Volume 3, Number 10.

Kermis, G. F. and Kermis, M. D. (2014). Financial Reporting Regulations, Ethics and Accounting Education. Journal of Academic and Business Ethics.

Mahdi, M. and Mohsen, K. (2012). Impact of Professional Ethics on Financial Reporting Quality.https://www.researchgate.net/publication/256022518_The_Impact_of_Professional_ Ethics_on_Financial_Reporting_Quality

Mantzke. Carnes. \& Tolhurst (2005). Ethics and Accounting Education in a Developing Country. Emerald Group Publishing Limited. www.emeraldinsight.com

Masoud, B. and Mahbude, A. (2013). Impact of Professional Ethics on Financial Reporting Quality. Advances in Environmental Biology. Volume 7, Number 10. www.aeb.net

Onyebuchi, V. N. (2011). Ethics in Accounting. International Journal of Business and Social Science. Volume 2 Number 10

Pandey, A. (2017). Ethical Issues of Financial Reporting. Open Access International Journal of Science and Engineering. Volume 2, Issue 3 


\section{International Conference on Advanced Research in MANAGEMENT, ECONOMICS AND ACCOUNTING}

\section{5-7 September, 2019}

\section{Barcelona, spain}

$\mathrm{M}_{\mathrm{E}} \mathrm{A}$

MANAGEMENT, ECONOMICS \& ACCOUNTING CONFERENCE

PWC Nigeria (2018). A Look at Current Financial Reporting Issues. www.pwc.com/sg/en/insurance/assets/ifrs17-current-financial-reporting.pdf

Resnik, D. (2010). What is Ethics in Research \& Why is it Important? National Institute of Health, US Department of Health \& Human Service

Talebinia, G. Salehi, M. and Jabbarzade (2011). Impact of Collapse Financial Reporting. African Journal of Business Management.

Ugbogbo, S. N. and Atu, O.M. (2016). Ethical Issues in Information Technology. A Conceptual Appraoch.Igbinedion University Journal of Accounting, Volume 2, Page 174

Valiance, R. J. (2004). Formation in Research Ethics: Developing a Teaching Approach for the Social Sciences. AARE Conference, The University of Melbourne, 28th November - 2nd December. White, M. (2002). Internet Research Ethics, Representations or People? Kluwer Academic Publishers

Yarahmadi, H. (2015). Ethics in Accounting. International Journal of Accounting and Financial Reporting. Volume 5, Number 1

\section{APPENDIX 1}

Department of Accounting

Faculty of Management Sciences

Ekiti State University

Dear Respondent,

This questionnaire aims at impact of ethics on financial report of corporate organizations in Nigeria. This is purely an academic upon which conclusion will be drawn based on your response.

This research work is in accordance with the doctoral degree in accounting.

Yours faithfully, 


\section{International Conference on Advanced Research in MANAGEMENT, ECONOMICS AND ACCOUNTING}

\section{5-7 September, 2019}

Moses Obasesin
Barcelona, spain
$\mathrm{M} \mathrm{A}$

MANAGEMENT, ECONOMICS \& ACCOUNTING CONFERENCE

\section{Impact of Ethics on Financial Report of Corporate Organizations in Nigeria questionnaire}

The essence of this questionnaire is for research purposes.

Section A: Please tick as appropriate

Department:

Educational Qualification: First Degree ( ) Second Degree ( ) Third Degree ( ) Others ( )

Section B: SA for Strongly Agree; A for Agree; D for Disagree; SD for Strongly Disagree

1. Business organizations are transparent in financial reporting; SA ( ) A ( ) D ( ) SD ( )

2. Ethical financial reporting is the responsibility of directors; SA ( ) A ( ) D ( ) SD ( )

3. There is sound internal control system; SA ( ) A ( ) D ( ) SD ( )

4. Management ethical or unethical decisions affect preparation of financial reporting;

SA ( ) A ( ) D ( ) SD ( )

5. Observed ethical irregularities in business reporting are largely a function of management's decision; SA ( ) A ( ) D ( ) SD ( )

6. There are statutory codes guiding business organizations operation; SA ( ) A ( ) D ( ) $\mathrm{SD}($ )

7. Level of supervision of business operation in Nigeria is not sound enough; SA ( )

$$
\mathrm{A}(\text { ) D ( ) SD ( ) }
$$

8. Management are supervised by relevant statutory codes; SA ( ) A ( ) D ( ) SD ( )

9. Available penalties to correct ethical irregularities are responsible to discourage unethical practices; SA ( ) A ( ) D ( ) SD ( )

10. Issued code ensures ethicality in business operations; SA ( ) A ( ) D ( ) SD ( ) 